\title{
Distribution of Hepatitis B Virus Genotypes in Azerbaijani Patients With Chronic Hepatitis B Infection
}

\author{
Farah Bokharaei Salim ${ }^{1,}$; Hossein Keyvani ${ }^{1}$; Seyed Hamidreza Monavari ${ }^{1}$; Maryam Esghaei ${ }^{1}$; \\ Shahin Fakhim ${ }^{2}$; Angila Ataei Pirkooh ${ }^{1}$; Bita Behnava ${ }^{3,4}$ \\ ${ }^{1}$ Department of Virology, Iran University of Medical Sciences, Tehran, IR Iran \\ ${ }^{2}$ Department of Civil Engineering, Faculty of Engineering, Payame Noor University, Karaj, IR Iran \\ ${ }^{3}$ Middle East Liver Diseases Center, Tehran, IR Iran \\ 4 Iran Hepatitis Network, Tehran, IR Iran \\ *Corresponding Author: Farah Bokharaei Salim, Department of Virology, Iran University of Medical Sciences, Tehran, IR Iran. Tel/Fax: +98-2188602205, E-mail: Bokharaei.f@iums.ac.ir
}

Received: November 3, 2014; Accepted: November 18, 2014

\begin{abstract}
Background: Hepatitis B virus (HBV) has been classified into ten genotypes (A-J) based on genome sequence divergence, which is very important for etiological and clinical investigations. HBV genotypes have distinct geographical distributions worldwide.

Objectives: The aim of this study was to investigate the distribution of HBV genotypes among Azerbaijani patients with chronic hepatitis $\mathrm{B}$, came from the Republic of Azerbaijan country to Iran to receive medical care.

Patients and Methods: One hundred and three patients with chronic HBV infection, referred to hospitals related to Iran University of Medical Sciences and Tehran Hepatitis Center from August 2011 to July 2014, were enrolled in this cross sectional study. About 3-milliliter of peripheral blood was taken from each patient. After viral DNA extraction, HBV genotypes were tested using the INNO-LiPA ${ }^{\mathrm{TM}} \mathrm{HBV}_{\mathrm{Kit}}$ (Innogenetics, Ghent, Belgium). HBV genotyping was confirmed using sequencing of hepatitis B surface antigen(HBsAg)and polymerase (pol) regions of HBV.

Results: The mean age of patients was $35.9 \pm 11.7$ years (19-66). Of 103 patients, $72(69.9 \%)$ were male. In the present study, the predominant HBV genotype was D (93.2\%) followed by genotype A (5.8\%) and concurrent infection with A and D genotypes (0.97\%).

Conclusions: The main and frequent HBV genotype among Azerbaijani patients with chronic hepatitis B virus infection was genotype D followed by genotype A.
\end{abstract}

Keywords:Hepatitis B virus; Genotype; Patients

\section{Background}

Hepatitis B virus (HBV) is an enveloped DNA virus belonging to the genus Orthohepadnavirus and the family Hepadnaviridae (1). Its genome is a small, circular partially double-stranded DNA molecule of approximately 3,200 nucleotides in length (2) including four overlapping open reading frames that code three hepatitis B surface proteins (HBsAg), two core proteins (HBc/ $\mathrm{HBeAg}$ ), the viral polymerase and $\mathrm{X}$ protein (HBx) (3). Hepatitis $B$ virus infection is the leading cause of chronic liver disease and estimated to affect 400 million people worldwide (4). Hepatitis B virus infection is an important cause of chronic liver disease in the Republic of Azerbaijan country and about $8 \%$ of Azerbaijani people have this infection. Hepatitis B virus has a high degree of genetic heterogeneity (inter-type differences) due to a high error rate of reverse transcriptase that this virus uses for viral replication (1). According to the sequence similarity, HBV is classified into eight genetic groups and named by capital alphabet letters (A to $\mathrm{H}$ ), which differ genetically of about $8 \%$ in complete nucleotide sequence (5). Recently, two genotypes (I and J) were proposed for
HBV strains $(6,7)$. HBV genotypes have been further divided into subgenotypes with inter-type differences greater than $4 \%$ (8). Hepatitis B virus genotype and subgenotypes have distinct ethno-geographical distribution (9); genotype A is the most prevalent one in the USA and Northern, Middle and Western Europe, South and Central Africa; genotype B in Asia; genotype C in East Asia and countries of the Pacific rim; genotype D predominant in the Mediterranean as well as the Middle East, India and North America $(10,11)$; genotype E in Africa; genotype F mainly detected in Central and South America as well as Alaska (12-14); genotype $\mathrm{H}$ in North and Central America and Mexico (15); genotype $G$ in North America and Europe (16-18). Some studies revealed that the incidence of liver disease and the degree of disease progression may differ for each HBV genotypes (9). HBV genotype D is predominantly found in Iran (19), Turkey (20), Iraq (21), Pakistan (22), Afghanistan (23), Russia (24), Belarus (25), Estonia (26), Latvia (27) and Uzbekistan (28).

Copyright (C) 2014, Kowsar Corp. This is an open-access article distributed under the terms of the Creative Commons Attribution-NonCommercial 4.0 International License (http://creativecommons.org/licenses/by-nc/4.0/) which permits copy and redistribute the material just in noncommercial usages, provided the original work is properly cited. 


\section{Objectives}

The aim of this study was to investigate the frequency of HBV genotypes among Azerbaijani patients with chronic hepatitis B came from the Republic of Azerbaijan country to Iran to receive medical treatment.

\section{Patients and Methods}

\subsection{Study Population}

From August 2011 to July 2014, one hundred and three Azerbaijani patients with established chronic hepatitis B (HBsAg and HBVDNA positive), came from the Republic of Azerbaijan country (one of the Newly Independent States of the former Soviet Union) to Iran for medical care, were enrolled in this cross-sectional study. The patients were referred to hospitals affiliated to Iran University of Medical Sciences and Tehran University of Medical Sciences. Informed consent was obtained from each patient. The present study was approved by the local ethics committee of Gastrointestinal and Liver Disease Research Center (GIDRC) of Iran University of Medical Sciences.

\subsection{Collection and DNA Extraction of Specimens}

About 3-milliliter of peripheral blood was drawn from all enrolled participants into EDTA-containing vacationer tubes. Plasma was taken and stored at $-80^{\circ} \mathrm{C}$ for later detection. HBV DNA was extracted from $200 \mu \mathrm{L}$ of plasma samples using DNA extraction kit (Qiagen GmbH, Hilden, Germany) according to the kit instructions. The quality and quantity of extracted DNA was determined with a nanodrop spectrophotometer (Thermo Scientific, Wilmington, USA) after DNA extraction.

\subsection{Hepatitis B Virus Genotyping}

Hepatitis B virus genotypes were analyzed in extracted viral DNA specimens using the INNO-LiPA ${ }^{\mathrm{TM}} \mathrm{HBV}$ kit (Innogenetics, Ghent, Belgium) according to the manufacturer's instructions. Briefly, HBV-DNA was amplified by nested-polymerase chain reaction (nested-PCR) method. PCR products were hybridized to HBV genotype-specific probes attached to nitrocellulose strips and then the hybrids were revealed with chromogen substrates. The results of HBV genotyping were interpreted using the kit interpretation chart. To confirm the INNO-LiPA HBV genotyping, hepatitis B surface antigen (HBsAg) and polymerase (Pol) regions of HBV from four randomly selected plasma samples were amplified with Ex Taq DNA polymerase [TaKaRa Biotechnology (Dalian) Co., Ltd., Shiga, Japan], then PCR products were sequenced.

\subsection{Hepatitis B Virus DNA Detection in Plasma Samples and Sequencing of Hepatitis B Surface Antigen (HBsAg) Region}

Hepatitis B surface antigen (HBsAg) region of HBV was amplified by nested-PCR method. Briefly, A set of nested primers from the HBsAg region of HBV was used, including an outer primer pair of 947-base span: sense primer S1 (5'-CCTGCTGGTGGCTCCAGTTC-3 ${ }^{\prime}$; 56-75), and antisense primer S2 (5 $5^{-}$-CCACAATTCKTTGACATACTTTCCA-3- $\mathrm{K}=\mathrm{G} / \mathrm{T}$; 1003-979) and an inner primer pair of 744base span: sense primer S6 (5 -GCACACGGAATTCCGAGGACTGGGGACCCTG-3; 113-146) and antisense primer S7 (5 -GACACCAAGCTTGGTTAGGGTTTAAATGTATACC-3 ${ }^{-}$; 857-823) (29). The first and second rounds PCR were performed in a $50 \mu \mathrm{L}$ mixture reaction containing 2.0 U Ex Taq DNA polymerase [TaKaRa Biotechnology (Dalian) Co., Ltd., Shiga, Japan], $5 \mu \mathrm{L}$ 10X Ex Taq buffer (Mg2+free), 4 $\mu \mathrm{L} \operatorname{MgCl} 2$ (25 mM), $4 \mu \mathrm{L}$ dNTPs Mixture (25 mM each), 20 pmol of each outer primers, and $5 \mu \mathrm{L}$ viral extracted DNA was used as a template for the first round of PCR and $1 \mu \mathrm{L}$ of the PCR-amplified product in the first round was used as a template for the second round of PCR. Thermal cycle profiles used for the nested-polymerase chain reaction assay were exactly as described previously (30). PCR products (744 bp) of samples, negative and positive controls and DNA size marker (100 bp) were isolated by $1.5 \%$ agarose gel electrophoresis, stained by ethidium bromide, and then visualized using an ultraviolet (UV) transilluminator. PCR-amplified products in the second round (744 bp) were purified using high pure PCR product purification kit (Roche Diagnostic GmbH, Mannheim, Germany) and then subjected to bidirectional sequencing with inner primers by dye termination method using the sequencer ABI version $3730 \mathrm{XL}$. The nucleotide sequences of HBsAg region of $\mathrm{HBV}$ announced in the present study were submitted to GenBank with the accession numbers from KM035536 to KM035539.

\subsection{Hepatitis B Virus DNA Detection in Plasma Samples and Sequencing of the Polymerase (Pol) Region}

Polymerase region of $\mathrm{HBV}$ was amplified using PCR method. Briefly, A set of primers was used for amplification of the polymerase region of $\mathrm{HBV}$, including a primer pair of 454-base span: sense primer P1 (5'-GTATTCCCATCCCATCATCC-3 ${ }^{\prime}$; 599-619) and antisense primer P2 (5`- CAAGGCAGGATAGCCACATT-3'; 1053-1033) (31). Polymerase chain reaction (PCR) was performed in a $50 \mu \mathrm{L}$ mixture reaction containing $1.5 \mathrm{U}$ Ex Taq DNA polymerase [TaKaRa Biotechnology (Dalian) Co., Ltd., Shiga, Japan], $5 \mu \mathrm{L}$ 10X Ex Taq buffer ( $\mathrm{Mg}^{2+}$ free), $3.5 \mu \mathrm{L} \mathrm{MgCl}_{2}(25$ $\mathrm{mM}), 4 \mu \mathrm{L}$ dNTPs Mixture (25 mM each), and $15 \mathrm{pmol}$ of each outer primers. Five microliters of viral extracted DNA was used as a template. Thermal cycle profiles used for the reaction were described previously (31). PCR products (454 bp) of samples, negative and positive controls and DNA size marker (100 bp) were isolated by $2 \%$ agarose gel electrophoresis, stained by ethidium bromide and then visualized by an UV transilluminator. The PCR-amplified product was purified using high pure PCR product 
Table 1. Demographic Characteristic, Laboratory Parameters and Hepatitis B Virus Genotypes Distribution Among Azerbaijani Patients $\mathrm{a}, \mathrm{b}$

\begin{tabular}{lcccc}
\hline Parameters & Female & Male & Total & PValue \\
\hline Patients & $31(30.1)$ & $72(69.9)$ & $103(100)$ & \\
\hline Age, Years & $36.1 \pm 13.9(19-66)$ & $35.9 \pm 10.7(21-64)$ & $36.0 \pm 11.7(19-66)$ & 0.885 \\
\hline Laboratory Parameters & & & & \\
\hline ALT, IU/L & $87.0 \pm 72.6(29.0-269.0)$ & $63.5 \pm 38.1(24.0-299.0)$ & $70.6 \pm 52.0(24.0-299.0)$ & 0.546 \\
\hline AST, IU/L & $70.7 \pm 57.0(11.0-172.0)$ & $48.9 \pm 35.8(19.0-182.0)$ & $55.2 \pm 44.1(11.0-182.0)$ & 0.269 \\
\hline Viral Load, IU/mL & $5155.0(122-55024405)$ & $3785.0(244-6321290000)$ & $4350.0(122-6321290000)$ & 0.678 \\
\hline Type of HBV Genotypes & & & & 0.362 \\
\hline D & $28(90.3)$ & $68(94.4)$ & $71(94.2)$ & $6(5.8)$ \\
\hline A & $3(9.7)$ & $3(4.2)$ & & 0.449 \\
\hline Mixed HBV Genotype & & & $1(0.97)$ & \\
\hline A and D & $0(0.0)$ & $1(1.4)$ & & \\
\hline
\end{tabular}

a Abbreviations: ALT, Alanine aminotransferase; AST, Aspartate aminotransferase.

$\mathrm{b}$ Data are presented as No. (\%) or Mean \pm SD (Range).

purification kit and then subjected to bidirectional sequencing with inner primers by dye termination method using the sequencer ABI version $3730 \mathrm{XL}$. The nucleotide sequences pol region of HBV announced in the current study was submitted to the GenBank with accession numbers from KM035540 to KM035543.

\subsection{Statistical Analysis}

Statistical analyses were performed using SPSS version 16 software (SPSS Inc., Chicago, IL, USA). Descriptive analyses as well as Student's t-test were used. $\mathrm{P}<0.05$ was considered statistically significant.

\section{Results}

One hundred and three patients with hepatitis B virus infection were recruited in this cross-sectional study. The mean \pm SD age of studied subjects was $35.9 \pm 11.7$ (range: 19-66 years). Of 103 patients, 72 (69.9\%) were male. The demographic characteristics, laboratory parameters and distribution of HBV genotypes in all participants are presented in Table 1 . HBV genotypes of the study population were determined as follows: genotype D in 96 (93.2\%) patients, genotype A in $6(5.8 \%)$ and mixed HBV infection (A and D) in $1(0.97 \%)$ patient. The frequency of genotype $A$ and $D$ in patients younger than 40 years were $8.1 \%$ and $91.8 \%$, respectively, which was not statistically significant. HBV genotypes of subjects' plasma specimen were confirmed via nucleotide sequencing of the HBV HBsAg and pol regions.

\section{Discussion}

Hepatitis B virus is a typical example of a virus with various genotypes and different geographic distributions worldwide. A genetic classification based on the comparison of HBV complete genomes defined ten genotypes (from A to J) (5-7). Molecular variation of the virus genome led to the emergence of HBV genotypes (32). The outcome of chronic hepatitis B virus infection is associated to variable viral factors such as HBV viral load, HBV genotypes, HBV variants and hepatitis B e antigen (HBeAg) status (33). The current study was performed on 103 Azerbaijani participants with chronic HBV infection, came from the Republic of Azerbaijan country to Iran to receive medical care, to determine the distribution of HBV genotypes in their plasma specimens. According to obtained results, the frequency of HBV genotypes of the study population was found as follows: genotype D was the most dominant (93.2\%), followed by genotype A (5.8\%) and concurrent infection with HBV genotype A and D in 1 (0.97\%) patient. Determination of HBV genotype is important to clarify the virulence, pathogenesis and rout of transmission of the virus (34). The former Soviet Union was considered as an area with high endemicity of hepatitis viruses and the present frequency of these infections are unknown in this region (28). Little is known about the distribution of HBV genotypes in the Republic of Azerbaijan country. This was the preliminary study performed on Azerbaijani patients, so we are unable to compare the results of this study with any other investigation. The most frequent HBV genotype in various areas of the former Soviet Union is genotype D as follows: Armenia (95.5\%) (32), Belarus (88.6\%) (25), Estonia (81.0\%) (26), Latvia (72.1\%) (27), Russia (93.0\%) (24), Tajikistan (94.1\%) (35), Ukraine (52.4\%) (36) and Uzbekistan (87.0\%) (28), which are consistent with the frequency of HBV genotype of the current study. Distribution of HBV genotypes and subtypes in some countries of the former Soviet Union (24-28, 32,35,36), Non-Arab countries including Afghanistan (35.7\%) (23), Iran (100.0\%) (19), Pakistan (58.5\%) (22), Turkey (100.0\%) (20) and Arab countries such as Iraq (100.0\%) (21), Jordan (100.0\%) (37), Kuwait (78.7\%) (38), Oman (76.5\%) (39), Saudi Arabia (81.4\%) (40) and the 
Bokharaei Salim F et al.

\begin{tabular}{|c|c|c|c|}
\hline \multirow[t]{2}{*}{ Region/Countries } & \multicolumn{2}{|c|}{ Genotypes and Subgenotypes } & \multirow[t]{2}{*}{ References } \\
\hline & Most Common & Less Common & \\
\hline \multicolumn{4}{|l|}{ The former Soviet nion } \\
\hline Armenia & $\mathrm{D}(95.5)$ & $\mathrm{A}(4.5)$ & Ghazinyan et al. (32) \\
\hline Belarus & $\mathrm{D}(88.6)$ & A2 (11.6) & Olinger et al.(6) \\
\hline Estonia & $\mathrm{D}(81.0)$ & $\mathrm{A}(18.5)$ & Tallo et al. (26) \\
\hline Latvia & $\mathrm{D}(72.1)$ & $\mathrm{A}(28.0), \mathrm{E}(0.9)$ & Sominskaya et al. (27) \\
\hline Russia & $\mathrm{D}(93.0)$ & - & Deterding et al. (24) \\
\hline Tajikistan & $\mathrm{D}(94.1)$ & $A(5.8)$ & Khan et al. (35) \\
\hline Ukraine & $\mathrm{D}(52.4)$ & $\mathrm{A}(14.2), \mathrm{C}(4.7)$ & Stepchenkova et al. (36) \\
\hline Uzbekistan & $\mathrm{D}(87.0)$ & $\mathrm{A}(13.0)$ & Kato et al. (28) \\
\hline \multicolumn{4}{|l|}{ Non-Arab Countries } \\
\hline Afghanistan & $\mathrm{D}(35.7)$ & $\mathrm{C}(32.2), \mathrm{A}(19.3), \mathrm{B}(7.0)$ & Attaullah et al.(23) \\
\hline Iran & $\mathrm{D}(100.0)$ & - & Vaezjalali et al. (19) \\
\hline Pakistan & $\mathrm{D}(58.5)$ & A (10), Mixed genotypes A and D (31.5) & Hanif et al. (22) \\
\hline Turkey & $\mathrm{D}(100.0)$ & - & Ozdemir et al. (20) \\
\hline \multicolumn{4}{|l|}{ Arab Countries } \\
\hline Iraq & $\mathrm{D}(100.0)$ & - & Khalid (21) \\
\hline Jordan & $\mathrm{D}(100.0)$ & - & Masaadeh et al. (37) \\
\hline Kuwait & $\mathrm{D}(78.7)$ & A (5.0), Mixed genotypes D and A (16.3) & Ali et al. (38) \\
\hline Oman & $\mathrm{D}(76.5)$ & $\mathrm{A}(18.3), \mathrm{C}(1.2), \mathrm{E}(1.2)$ & Al Baqlani et al. (39) \\
\hline Saudi Arabia & $\mathrm{D}(81.4)$ & E (5.7), A (1.4), C (1.4), Mixed genotypes (10.0) & Abdo et al. (40) \\
\hline The United Arab Emirates & $\mathrm{D}(79.5)$ & $\mathrm{A}(18.2), \mathrm{C}(2.3)$ & Alfaresi et al. (41) \\
\hline
\end{tabular}

United Arab Emirates (79.5\%) (41) are shown in Table 2. HBV genotypes have a distinct geographic distribution worldwide. Hepatitis B virus genotype D is found all over the world; it is the most prevalent genotype in the Mediterranean basin, the Middle East, north-eastern Europe, northern Africa and the Indian subcontinent, also it has been detected in Oceania (1). Global distribution of HBV genotypes may change over time because of the population migration (32). The origin of HBV D genotype, subgenotypes and their expansion throughout the world is still unknown. Zehender et al. suggested that the Indian subcontinent was the location in which HBV genotype D originated. Their suggestion is supported by the fact that genotype $\mathrm{D}$ is the most prevalent in India (1). There are a few data available regarding HBV genotype prevalence in central Asia, but HBV D genotype is the most prevalent genotype in the region (1). In this study, all patients infected by HBV genotype A were younger than 40 years. This is interesting and needs more studies with larger population size. In conclusion, the current study showed that the predominant HBV genotype in Azerbaijani patients with established chronic hepatitis B is genotype $\mathrm{D}(93.2 \%)$ followed by genotype A (5.3\%). The current research was a preliminary study on HBV genotyping. However, it is suggested to perform further investigations to determine HBV subgenotyping in these patients.

\section{Acknowledgements}

We wish to thank all the volunteers who generously participated in the present research.

\section{Authors' Contributions}

Farah Bokharaei-Salim designed the present study and responsible for the overall study management. Farah Bokharaei-Salim and Hossein Keyvani organized the study analysis. Farah Bokharaei-Salim, Hossein Keyvani, Seyed Hamidreza Monavari, Maryam Esghaei, Shahin Fakhim, Angila Ataei Pirkooh and Bita Behnava prepared the manuscript. The statistical analyses were performed by Farah Bokharaei-Salim and Shahin Fakhim. All authors contributed to the final version of the manuscript.

\section{Funding/Support}

This study was supported by the Research Deputy of Iran University of Medical Sciences, grant number of 23413.

\section{References}

1. Zehender G, Ebranati E, Gabanelli E, Shkjezi R, Lai A, Sorrentino C, et al. Spatial and temporal dynamics of hepatitis B virus D genotype in Europe and the Mediterranean Basin. PLoS One. 2012;7(5).

2. Pujol FH, Navas MC, Hainaut P, Chemin I. Worldwide genetic diversity of HBV genotypes and risk of hepatocellular carcinoma Cancer Lett. 2009;286(1):80-8. 
3. Rodriguez-Inigo E, Bartolome J, Ortiz-Movilla N, Platero C, LopezAlcorocho JM, Pardo M, et al. Hepatitis C virus (HCV) and hepatitis B virus (HBV) can coinfect the same hepatocyte in the liver of patients with chronic HCV and occult HBV infection.J Virol. 2005;79(24):15578-81.

4. Kim BK, Revill PA, Ahn SH. HBV genotypes: relevance to natural history, pathogenesis and treatment of chronic hepatitis B. Antivir Ther. 2011;16(8):1169-86.

5. Schaefer S. Hepatitis B virus genotypes in Europe. Hepatol Res. 2007;37(s1):S20-6.

6. Olinger CM, Jutavijittum P, Hubschen JM, Yousukh A, Samountry $\mathrm{B}$, Thammavong T, et al. Possible new hepatitis B virus genotype, southeast Asia. Emerg Infect Dis. 2008;14(11):1777-80.

7. Tatematsu K, Tanaka Y, Kurbanov F, Sugauchi F, Mano S, Maeshiro $\mathrm{T}$, et al. A genetic variant of hepatitis B virus divergent from known human and ape genotypes isolated from a Japanese patient and provisionally assigned to new genotype J. J Virol. 2009;83(20):10538-47.

8. Gunther S. Genetic variation in HBV infection: genotypes and mutants. J Clin Virol. 2006;36 Suppl 1:S3-S11.

9. Guettouche T, Hnatyszyn HJ. Chronic hepatitis B and viral genotype: the clinical significance of determining HBV genotypes. Antivir Ther. 2005;10(5):593-604.

10. Arankalle VA, Murhekar KM, Gandhe SS, Murhekar MV, Ramdasi AY, Padbidri VS, et al. Hepatitis B virus: predominance of genotype D in primitive tribes of the Andaman and Nicobar islands, India (1989-1999). J Gen Virol. 2003;84(Pt 7):1915-20.

11. Gandhe SS, Chadha MS, Arankalle VA. Hepatitis B virus genotypes and serotypes in western India:lack of clinical significance. JMed Virol. 2003;69(3):324-30.

12. Pineiro y Leone FG, Mbayed VA, Campos RH. Evolutionary history of Hepatitis B virus genotype F: an in-depth analysis of Argentine isolates. Virus Genes. 2003;27(1):103-10.

13. Suzuki S, Sugauchi F, Orito E, Kato H, Usuda S, Siransy L, et al. Distribution of hepatitis B virus (HBV) genotypes among HBV carriers in the Cote d'Ivoire: complete genome sequence and phylogenetic relatedness of HBV genotype E. J Med Virol. 2003;69(4):459-65.

14. Sanchez-Tapias JM, Costa J, Mas A, Bruguera M, Rodes J. Influence of hepatitis B virus genotype on the long-term outcome of chronic hepatitis B in western patients. Gastroenterology. 2002;123(6):1848-56.

15. Arauz-Ruiz P, Norder H, Robertson BH, Magnius LO. Genotype $\mathrm{H}$ a new Amerindian genotype of hepatitis B virus revealed in Central America. J Gen Virol. 2002;83(Pt 8):2059-73.

16. Kremsdorf D, Garreau F, Capel F, Petit MA, Brechot C. In vivo selection of a hepatitis B virus mutant with abnormal viral protein expression. J Gen Virol.1996;77 ( Pt 5):929-39.

17. Stuyver L, De Gendt S, Van Geyt C, Zoulim F, Fried M, Schinazi RF, et al. A new genotype of hepatitis B virus: complete genome and phylogenetic relatedness. J Gen Virol. 2000;81(Pt 1):67-74.

18. Kato H, Orito E, Gish RG, Sugauchi F, Suzuki S, Ueda R, et al. Characteristics of hepatitis B virus isolates of genotype $G$ and their phylogenetic differences from the other six genotypes (A through F).J Virol. 2002;76(12):6131-7.

19. Vaezjalali M, Alavian SM, Jazayeri SM, Nategh R, Mahmoodi M, Hajibeigi B, et al. Genotype of hepatitis B virus isolates from Iranian chronic carriers of the virus. Hepat mon. 2008;8(2):97-100.

20. Ozdemir FT, Duman D, Ertem D, Avsar E, Eren F, Ozdogan O, et al. Determination of hepatitis B genotypes in patients with chronic hepatitis B virus infection in Turkey. Turk J Gastroenterol. 2005;16(4):183-7.

21. Khalid MD. Determination of Hepatitis $B$ virus genotypes among HBSAgpositive Blood donors in Mosul central Blood Bank. Iraq; 2014.

22. Hanif M, Zaidi P, Habib S, Ahmed A, Raza A, Shahnaz Murtaza SA, et al. Study of genotypes and subgenotypes of Hepatitis
B virus prevalent in big cities of Pakistan. Afr J Microbiol Res. 2013;7(3):152-7.

23. Attaullah S, Rehman S, Khan S, Ali I, Ali S, Khan SN. Prevalence of hepatitis B virus genotypes in HBsAg positive individuals of Afghanistan. Virol J. 2011;8:281.

24. Deterding K, Constantinescu I, Nedelcu FD, Gervain J, Nemecek V, Srtunecky O, et al. Prevalence of HBV genotypes in Central and Eastern Europe. J Med Virol. 2008;80(10):1707-11.

25. Olinger CM, Lazouskaya NV, Eremin VF, Muller CP. Multiple genotypes and subtypes of hepatitis B and C viruses in Belarus: similarities with Russia and western European influences. Clin Microbiol Infect. 2008;14(6):575-81.

26. Tallo T, Norder H, Tefanova V, Krispin T, Priimagi L, Mukomolov $\mathrm{S}$, et al. Hepatitis B virus genotype D strains from Estonia share sequence similarity with strains from Siberia and may specify ayw4. J Med Virol. 2004;74(2):221-7.

27. Ranka R, Petrovskis I, Sominskaya I, Bogans J, Bruvere R, Akopjana I, et al. Fibronectin-binding nanoparticles for intracellular targeting addressed by B. burgdorferi BBK32 protein fragments. Nanomedicine. 2013;9(1):65-73.

28. Kato H, Ruzibakiev R, Yuldasheva N, Hegay T, Kurbanov F, Achundjanov B, et al. Hepatitis B virus genotypes in Uzbekistan and validity of two different systems for genotyping. J Med Virol. 2002;67(4):477-83.

29. Gunther S, Li BC, Miska S, Kruger DH, Meisel H, Will H. A nove method for efficient amplification of whole hepatitis B virus genomes permits rapid functional analysis and reveals deletion $\mathrm{mu}-$ tants in immunosuppressed patients. JVirol.1995;69(9):5437-44.

30. Goodarzi Z, Malekzadeh R, Montazeri G. , Alavian SM, Qurbanalizadgan M, Daram M. Phylogenetic analysis of HBV based on PreS region in Iranian hepatocellular carcinoma patients. Hepat Mon. 2007;7(4):201-5.

31. Lu HY, Zeng Z, Xu XY, Zhang NL, Yu M, Gong WB. Mutations in surface and polymerase gene of chronic hepatitis $B$ patients with coexisting HBsAg and anti-HBs. World $J$ Gastroenterol. 2006;12(26):4219-23.

32. Ghazinyan H, Asoyan A, Mkhitaryan A, Melik Andreasyan G. Hepatitis B Virus Genotypes in Armenian Patients With Acute and Chronic HBV Infection. Blood. 2013;1(15)

33. Tanwar S, Dusheiko G. Is there any value to hepatitis B virus genotype analysis? Curr Gastroenterol Rep. 2012;14(1):37-46.

34. Kramvis A, Kew M, Francois G. Hepatitis B virus genotypes. Vaccine. 2005;23(19):2409-23.

35. Khan A, Kurbanov F, Tanaka Y, Elkady A, Sugiyama M, Dustov A, et al. Epidemiological and clinical evaluation of hepatitis B, hepatitis C, and delta hepatitis viruses in Tajikistan. J Med Virol. 2008;80(2):268-76.

36. Stepchenkova T, Karnets I, Ashworth K, Cheusova T. The results of a study on the prevalence of HIV, HCV and HBV genotypes in some regions of Ukraine. Retrovirology . 2012;9(Suppl 1):55.

37. Masaadeh HA, Hayajneh WA, Alqudah EA. Hepatitis B virus genotypes and lamivudine resistance mutations in Jordan. World $J$ Gastroenterol. 2008;14(47):7231-4.

38. Ali MM, Hasan F, Ahmad S, Al-Nakib W. Comparative evaluation of INNO-LiPA HBV assay, direct DNA sequencing and subtractive PCR-RFLP for genotyping of clinical HBV isolates. Virol J. 2010;7:111.

39. Al Baqlani SA, Sy BT, Ratsch BA, Al Naamani K, Al Awaidy S, Busaidy SA, et al. Molecular epidemiology and genotyping of hepatitis B virus of HBsAg-positive patients in Oman. PLoS One. 2014;9(5).

40. Abdo AA, Al-Jarallah BM, Sanai FM, Hersi AS, Al-Swat K, Azzam NA et al. Hepatitis B genotypes: relation to clinical outcome in patients with chronic hepatitis B in Saudi Arabia. World J Gastroenterol. 2006;12(43):7019-24.

41. Alfaresi M, Elkoush A, Alshehhi H, Alzaabi A, Islam A. Hepatitis B virus genotypes and precore and core mutants in UAE patients. Virol J. 2010;7:160. 